\title{
Audit Committee's Role in Moderating the Effect of Financial Distress Towards Going Concern Audit Opinion
}

\author{
Anna Kania Widiatami ${ }^{1}$, Nanny Dewi Tanzil ${ }^{2}$, Cahya Irawadi ${ }^{2} \&$ Ahmad Nurkhin ${ }^{1}$ \\ ${ }^{1}$ Universitas Negeri Semarang, Indonesia \\ ${ }^{2}$ Universitas Padjadjaran, Indonesia \\ Correspondence: Anna Kania Widiatami, Universitas Negeri Semarang, Indonesia.
}

Received: December 27, 2019

Accepted: March 31, 2020

Online Published: July 7, 2020

doi:10.5430/ijfr.v11n4p432

URL: https://doi.org/10.5430/ijfr.v11n4p432

\begin{abstract}
Auditors are required to provide services in auditing financial statements presented by management and provide audit opinions on the fairness of the presentation of financial statements. Sometimes, in reality, management and auditors have their interests so that each party can achieve the goals. The conflict of interest appears on the independence of the auditor in issuing audit opinions, especially the audit opinion with the going concern explanatory paragraph. The audit committee, as a supervisory board, will continue to maintain the independence of the auditor in issuing audit opinions with the going concern explanatory paragraph. This study aims to examine the effectiveness of the audit committee in maintaining the independence of external auditors issuing audit opinions, especially the audit opinion with the going concern explanatory paragraph. Based on the purposive sampling method obtained a sample of 168 companies. Testing the hypothesis in this study using logistic regression and moderated regression analysis. The results showed that financial distress had a significant negative effect for the audit opinion with going concern explanatory paragraph. Furthermore, the audit committee was not able to strenghten the relationship of financial distress on the audit opinion with a going-concern explanatory paragraph.
\end{abstract}

Keywords: going concern, financial distress, audit committee, logistic regression, moderated regression analysis

\section{Introduction}

The global economic crisis that has occurred in recent years has weakened economic growth in various countries, including Indonesia. One of the industries affected by the economic crisis is in the mining sector. Indonesia Stock Exchange (IDX) was suspending several mining companies in share trades during 2016. Several issuers from the mining sector were given suspended sanctions because of their unsustainable performance even they have unclear income. The Indonesia Stock Exchange (IDX) stopped trading these shares because it questioned the issuer's business going concern. One of the criteria of a company called not having a business continuity is if it does not have income or its performance continues to lose money.

Table 1. Reference coal price data 2011-2016

\begin{tabular}{lllllll}
\hline & $\mathbf{2 0 1 1}$ & $\mathbf{2 0 1 2}$ & $\mathbf{2 0 1 3}$ & $\mathbf{2 0 1 4}$ & $\mathbf{2 0 1 5}$ & $\mathbf{2 0 1 6}$ \\
\hline January & 112,40 & 109,29 & 87,55 & 81,90 & 63,84 & 53,20 \\
\hline February & 127,05 & 111,58 & 88,35 & 80,44 & 62,92 & 50,92 \\
\hline March & 122,43 & 112,87 & 90,09 & 77,01 & 67,76 & 51,62 \\
\hline April & 122,02 & 105,61 & 88,56 & 74,81 & 64,48 & 52,32 \\
\hline May & 117,61 & 102,12 & 85,33 & 73,60 & 61,08 & 51,20 \\
\hline June & 119,03 & 96,65 & 84,87 & 73,64 & 59,59 & 51,81 \\
\hline July & 118,24 & 87,56 & 81,69 & 72,45 & 59,16 & 53,00 \\
\hline August & 117,21 & 84,65 & 76,70 & 70,29 & 59,14 & 58,37 \\
\hline September & 116,26 & 86,21 & 76,89 & 69,69 & 58,21 & 63,93 \\
\hline October & 119,24 & 86,04 & 76,61 & 67,26 & 57,39 & 69,07 \\
\hline November & 116,65 & 81,44 & 78,13 & 65,70 & 54,43 & 84,89 \\
\hline December & 112,67 & 81,75 & 80,31 & 64,65 & 53,51 & 101,69 \\
\hline Mean & $\mathbf{1 1 8 , 4 0}$ & $\mathbf{9 5 , 4 8}$ & $\mathbf{8 2 , 9 2}$ & $\mathbf{7 2 , 6 2}$ & $\mathbf{6 0 , 1 3}$ & $\mathbf{6 1 , 8 4}$ \\
\hline
\end{tabular}

Source: www.minerba.esdm.go.id, 2017 
Table 1 shows the decline in commodity prices in the mining sector business in the coal industry from 2011 to 2016 . In recent years the coal industry has experienced a decline in selling prices continuously, which has resulted in declining revenues for coal mining companies. This phenomenon affecting Indonesia Stock Exchange (IDX) suspended several mining companies from trade shares during 2016.

The financial statements presented by the company are a reflection of financial performance for a period. The profits obtained continuously indicate that the company has no financial difficulties or has excellent financial performance (Widhiastuti, Nurkhin, \& Susilowati, 2019). Financial distress often determines the failure or bankruptcy of each company. Financial distress interpreted as an essential event in the separation of time from the financial health of a company from the financial illness period. It requires corrective action to overcome the problematic situation (Outecheva, 2007). While bankruptcy can be declared by small traders as an inability to pay the rent and must stop its activities, or can be defined for large manufacturing companies as a lack of liquidity and suffer annual losses (Ghodrati $\&$ Moghaddam, 2012). From this definition, the conclusion is that financial distress and bankruptcy are not the same. Financial distress is only one of the causes of bankruptcy, but that does not mean that all companies facing financial distress will experience bankruptcy. Company managers could take corrective steps to avoid the company's bankruptcy if financial problems were detecting earlier. Information related to business continuity is needed for users of financial statements. Creditors worried a bankrupt company will make them return the remaining value of the company (Swanson \& Theis, 2019). As well as investors, they can understand the situation that occurs in listed companies and can adjust the investment strategy of investors to reduce investment related to these losses (Geng, Bose, \& Chen, 2015). For this reason, users of the financial statement need the accuracy of financial statements in reflecting the actual situation.

The auditor's role is needed to provide services in auditing and giving opinions on financial statements presented by management. Following the auditing standards, one of the opinions issued by the auditor is the audit opinion with the explanatory paragraph regarding the business continuity of the company. The auditor will issue audit opinion with going concern explanatory paragraph when there is significant doubt about the survival of the company that disclosed by management in the financial statements (Purba, 2016). Alternatively, the company that will go bankrupt (Read \& Yezegel, 2018). The company with solvability problems shows the probability of receiving qualified opinion audit higher than others (García Blandón \& Argilés Bosch, 2013). The auditor will provide an audit opinion with the going concern explanatory paragraph to the company that is experiencing financial problems and will experience bankruptcy. The management will disclose adequate information and the ability of the entity to maintain the survival of the company in the long term and not be liquidated within one year. When disclosure of information in financial statements provides evidence of financial difficulties and probabilities of business continuity, going concern opinion is an additional communication by the external auditor (Blay, Geiger, \& North, 2011). It means that auditor has substantial doubts about the company's business continuity based on their professional judgment (Carcello \& Neal, 2000; Knechel \& Vanstraelen, 2007; Triani, Satyawan, \& Yanthi, 2017).

However, there are previous studies that have different results from the theory above. Financial conditions do not affect the acceptance of the audit opinion with the going concern explanatory paragraph. The financial position that suddenly declines is not causing the probability of obtaining a going concern audit opinion but on the continuous losses (Gallizo, 2016). The auditor might have lost its independence due to too long an audit engagement with the same client (Januarti, 2009). Alternatively, the auditor may be afraid by giving a going concern opinion will make the company go bankrupt because investors will withdraw their funds (Rahayuningsih, 2014). With the result that the auditor continues to provide an opinion without modification, even the client is experiencing financial problems.

For that reason, it needs the supervision of both the auditor and management in carrying out their respective duties (Ika \& Ghazali, 2012). The audit committee, as the supervisory board, is responsible for supervising financial reporting, internal control, and external auditor activities. The audit committee, as a supervisory board, is expected to prevent conflict of interest between management and auditors in the audit engagement. The presence of an audit committee will increase the financial reporting process because giving understanding and information related to the financial statement (Inaam \& Khamoussi, 2016). An independent audit committee will achieve better transparency and improve the quality and credibility of financial information and protect the auditor from the threat of replacement from management after issuing a going concern audit opinion (Carcello \& Neal, 2003; Pucheta-martínez \& Fuentes, 2007).

Inversely, some previous studies found that audit committee characteristics not improving the quality of financial reporting (Wiralestari \& Tanzil, 2015). The number of independent members of the audit committee has a negative impact on bank financial performances as a means of ROA, ROE, and NIM (Gunes \& Atilgan, 2016). An audit committee that was often doing a meeting does not prevent earning management practice in the company (Zgarni, 
Fadhila, \& El Gaied, 2018). Furthermore, the audit committee with accounting and managerial experience has a negative relation to audit quality (Yasin \& Nelson, 2012). Even in the UK, audit committees with non-financial expertise are more recommended. Perhaps an audit committee with non-financial expertise less confident to supervise the financial statement process. So that push more intensive external auditors than an audit committee with financial expertise (Ghafran \& O’Sullivan, 2017).

Based on the diversity of the results of research in previous studies, this study tries to test the effectiveness of audit committees in moderating financial problems or financial distress experienced by companies in obtaining audit opinions with the going concern explanatory paragraph. The objectives of this study to know the magnitude of the effect of financial distress on the acceptance of the audit opinion with the going concern explanatory paragraph; (2) to know the magnitude of the audit committee in moderating the effect of financial distress on audit opinions with the going concern explanatory paragraphs. This research expected to contribute to the development of theory and knowledge in the field of accounting, especially science related to auditing and financial accounting. It can be additional literature for future research. Also, the researcher expects to consider the effectiveness of the audit committee in carrying out its duties and obligations for the company.

\section{Hypotheses Development}

Financial distress is not bankruptcy. Financial distress is only one of the causes of bankruptcy, but that does not mean that all companies that experience financial distress will experience bankruptcy. Predictions of financial distress are a method based on estimates of whether the company has the potential to face bankruptcy (Omelka, Beranova, \& Tabas, 2013). In general, the most significant predictors of bankruptcy are using profitability, liquidity, and solvency ratios (Altman, 1968). A company with weak profitability and solvency considered to have potential bankruptcy. Companies that experience financial distress towards bankruptcy divided into several stages, among others (Kordestani, Biglari, \& Bakhtiari, 2011):

1. Latency stage. The company experienced a decrease in Return on Assets (ROA)

2. Shortage of cash flow stage. In the second stage, the company will experience shortages in cash flow. They do not have enough cash resources to meet short-term obligations, although they still have a strong background in profitability.

3. Financial distress. The company experiences financial distress, which financial emergency needed as it approaching bankruptcy.

4. Bankruptcy. If the company is unable to handle financial distress, they will experience bankruptcy.

Auditors who audit the companies that experience financial distress will question the business continuity of the company. Bankrupt companies have lower bankruptcy prediction scores. The more the results of the bankruptcy prediction score show negative results, indicating more significant financial weakness in the client so that the higher the possibility to accept going concern opinion. Because sick companies have many indicators of going concern problems (Carcello \& Neal, 2000; Knechel \& Vanstraelen, 2007; Ramadhany, 2004). The auditor will issue audit opinion with going concern explanatory paragraph to the company that will go bankrupt (Read \& Yezegel, 2018). Based on the theory and results of previous studies, the hypotheses in this study are as follows:

$\mathrm{H}_{1}$ : The smaller the prediction score of bankruptcy on the company, the more likely the acceptance of the audit opinion with the going concern explanatory paragraph.

The financial statements presented by the company are a reflection of the company's financial performance for one period. However, in reality, management wants the financial statements that produced to have good performance still, though the company is experiencing financial problems. Therefore, investors are interested in investing in the company. One characteristic of companies having good financial performance is getting an audit opinion without modification. So to obtain this opinion, management may oppose the auditor to issue a going concern opinion. Management might threaten to decide on the engagement with the auditor if it does not issue an opinion without modification. As a result of the threat, the auditor is afraid of losing clients. The auditor wants to maintain the income and expects the fee to be even greater in the future, so they are interested in having an audit engagement for a long time with the same client. (Carcello $\&$ Neal, 2000, 2003; Gavious, 2007). The existence of a conflict of interest can lead to a decrease in the independence of auditors to issue audit opinions with the going concern explanatory paragraph on companies that experience financial distress.

To suppress the emergence of conflict of interest from management and the auditor needs the existence of an audit committee as a supervisory board. The audit committee formed to help the board of commissioners carry out their 
duties in conducting supervision. In Indonesia, the duties and responsibilities of the audit committee are regulated in Rule No. IX.1.5: concerning the Establishment and Work Guidelines of the Audit Committee, Appendix to the Decision of the Chairman of Bapepam No. 643 / BL / 2012. The purpose of issuing the regulation is, it can increase independence and improve the duties, responsibilities, and authority of the Audit Committee. The audit committee's responsibilities are helping carry out the duties and functions of the board of commissioners as supervisors of the company. The presence of an audit committee will increase the financial reporting process because giving understanding and information related to the financial statement (Inaam \& Khamoussi, 2016).

A competent audit committee will safeguard the auditor in maintaining its independence, provide transparent information, improve quality and credibility in the company's financial statements, and keep the company compliant with applicable regulations. The composition of members, the size of the audit committee members, and the frequency of meetings are some indicators of the effectiveness of the audit committee (Carcello \& Neal, 2000). Previous research proves that the higher the presentation of affiliate directors on the audit committee, the lower the possibility of receiving going concern opinion. Another research finds, the size of audit committees and independent member presentations had a significant effect on the possibility of companies receiving unqualified opinions except for errors or non-compliance within the company (Pucheta-martínez \& Fuentes, 2007). Therefore, to ease the pressure given by management to the auditor and can maintain their independence to issue an audit opinion with the going concern explanatory paragraph needs the audit committee that effective. The auditor can issue an audit opinion with the going concern explanatory paragraph though they have had a long engagement with the same auditee. The presence of an audit committee indicates a higher quality audit (Inaam \& Khamoussi, 2016). Based on the theory and results of the research, the next hypothesis in this research is as follows:

$\mathrm{H}_{2}$ : An effective audit committee can strengthen companies experiencing financial distress to accept audit opinions with the going concern explanatory paragraph.

\section{The Method, Data, and Analysis}

The companies chosen to be the research sample are companies listed on the Indonesia Stock Exchange. The type of data used is secondary data consisting of independent auditor reports and annual reports from 2011-2018 obtained from the Indonesia Stock Exchange website and related company websites. Detail samples in the study explained in Table 2.

Table 2. Process of sample selection based on criteria

\begin{tabular}{llll}
\hline No & Criteria & Violation of Criteria & Accumulation \\
\hline $\mathbf{1}$ & $\begin{array}{l}\text { Total mining companies on the IDX as of December 31, } \\
2018\end{array}$ & 40 \\
\hline $\mathbf{2}$ & $\begin{array}{l}\text { The company that listed on the IDX in the mining sector } \\
\text { before January 1, 2011 }\end{array}$ & 34 \\
\hline $\mathbf{3} \quad$ The company that not delisted during the year of observation & -6 & 28 \\
\hline $\mathbf{4} \quad \begin{array}{l}\text { The company attaches an independent auditor's report and } \\
\text { audit committee report during 2011-2018 }\end{array}$ & 21 \\
\hline Number of sample companies & & 21 \\
\hline Year of observation in research & & \\
\hline Total number of samples during the study period & 168 \\
\hline
\end{tabular}

Financial distress or the financial condition of the company is an independent variable in this study. To calculate the financial condition of the company will be using the Altman Z-Score prediction model. The Altman Z-Score bankruptcy prediction model is most often used to predict the bankruptcy of a company. The Altman Z-Score bankruptcy prediction model has a high level of accuracy in predicting bankruptcy, which is up to 95\% (Altman, 1968; Ghodrati \& Moghaddam, 2012). Z-Score approach has proven to estimate that more than $80 \%$ of entities are in the "distress zone" (Altman, 2018). The Altman Z-Score formula is as follow:

$$
\begin{aligned}
\mathrm{Z} & =1,2(\text { Working Capital)/(Total Assets) }+1,4 \text { (Retained Earning)/(Total Assets) }+3,3 \mathrm{EBIT} / \text { (Total Assets) } \\
& +0,6 \text { (Market Value of Equity)/ (Book Value of Total Debt) }+0,999 \text { Sales/ (Total Assets) }
\end{aligned}
$$

With the cut-off value: 
$\mathrm{Z}<1,81=$ bankrupt

$1,81-2,99=$ grey area

$\mathrm{Z}>2,99=$ non-bankrupt

The dependent variable in this study is audit opinion with going concern explanatory paragraph (GC). Audit opinion with going concern explanatory paragraph is a dummy variable with the provision of the audit opinion with the going concern explanatory paragraph (GC) coded 1 and in addition to the audit opinion with the going concern explanatory paragraph (NGC) coded 0.

In this study, the moderating variable is using the effectiveness of the audit committee. An effective audit committee will strengthen companies experiencing financial problems to receive audit opinions with the going concern explanatory paragraph. The measurement of the audit committee's performance effectiveness in this study uses a measurement index. The index is consisting of four elements and divided into ten requirements that have been adjusted to the Bapepam Regulation or now OJK (Ika \& Ghazali, 2012). The index table measures the effectiveness of the performance of the audit committee as follows:

Table 3. Audit committee performance effectiveness measurement index

\begin{tabular}{|c|c|c|c|}
\hline Dimension & Code & Proxies & Scoring \\
\hline \multirow{2}{*}{ Composition } & ACIND & $\begin{array}{l}\text { Audit Committee Independence: } \\
\text { Members consist of Independent Commissioners and } \\
\text { outside parties }\end{array}$ & $\begin{array}{l}\text { Independent: } 1 \\
\text { Not Independent: } 1\end{array}$ \\
\hline & ACEXP & $\begin{array}{l}\text { Audit Committee Expertise: } \\
\text { Must have at least one member who has an educational } \\
\text { background and expertise in accounting/finance }\end{array}$ & $\begin{array}{l}\text { Expert: } 1 \\
\text { Not Expert: } 0\end{array}$ \\
\hline \multirow[b]{2}{*}{ Authority } & ACCHART & $\begin{array}{l}\text { Audit Committee Charter: } \\
\text { Must have an audit committee charter }\end{array}$ & $\begin{array}{l}\text { Yes: } 1 \\
\text { No: } 0\end{array}$ \\
\hline & ACDUTY & $\begin{array}{l}\text { Audit Committee Duty: } \\
\circ \quad \text { Reviewing financial information issued by the } \\
\text { company include financial statements, projections, and } \\
\text { other financial information } \\
\circ \quad \text { Reviewing company compliance with applicable } \\
\text { laws and regulations } \\
\circ \text { Reviewing external audit activity } \\
\circ \text { Review the effectiveness of the company's internal } \\
\text { controls }\end{array}$ & $\begin{array}{l}\text { Detailed explanation: } \\
2 \\
\text { A brief explanation: } 1 \\
\text { No explanation: } 0\end{array}$ \\
\hline Resources & ACSIZE & $\begin{array}{l}\text { Audit Committee Size: } \\
\text { Have at least three members }\end{array}$ & $\begin{array}{l}\geq 3: 1 \\
<3: 0\end{array}$ \\
\hline \multirow[b]{2}{*}{ Diligence } & ACMEET & $\begin{array}{l}\text { Audit Committee Meeting: } \\
\text { Held meetings at least once in three months or fourth } \\
\text { times in a year }\end{array}$ & $\begin{array}{l}\geq 4 \text { times in a year: } 1 \\
<4 \text { times in a year: } 0\end{array}$ \\
\hline & ACDISC & $\begin{array}{l}\text { Audit Committee Disclosure: } \\
\text { Audit committees are required to make reports on each } \\
\text { assignment and annual report on the implementation of } \\
\text { activities }\end{array}$ & $\begin{array}{l}\text { Yes: } 1 \\
\text { No: } 0\end{array}$ \\
\hline
\end{tabular}

Each requirement points, except the proxy of Audit Committee Duty, will be given a score of 1 if it has fulfilled the criteria and a score of 0 if it does not meet the criteria. The criteria stated in the regulations required by the Bapepam or now OJK. Proxy assessment of Audit Committee Duty on the element authority has a different assessment. It will be given score 2 for the points described in full, score 1 for brief explanations, and 0 if not explained at all. The highest total score of the index measuring the effectiveness of the audit committee's performance is 14 points. 
The hypothesis in this study tested using Logistic Regression Analysis and Moderated Regression Analysis. Logistic regression analysis used to test whether the financial distress variable affects the audit opinion with the going concern explanatory paragraph. The formula of the logistic regression model used to test the hypothesis in this study is as follows:

$$
\mathrm{GC}=\alpha+\beta_{1} \mathrm{ZSCORE}+\varepsilon
$$

Where:

$\mathrm{GC}=$ audit opinion with the going concern explanatory paragraph. It is dummy variable, score 1 if the company get an audit opinion with a going concern explanatory paragraph, 0 if the others

ZSCORE $=$ Bankruptcy prediction model using Altman Z-Score.

$\alpha=$ constant

$\beta 1=$ regression coefficient

$\varepsilon=$ residual error

MRA used to test whether the audit committee strengthens influence financial distress towards audit opinion with the going concern explanatory paragraph. As the formula of moderated regression analysis that used to test the hypothesis in this study is as follows:

$$
\mathrm{GC}=\alpha+\beta_{2} \text { ZSCORE }+\beta_{3} \text { AUDCOM }+\beta_{4} \text { ZSCORE.AUDCOM }+\varepsilon
$$

Where:

$\mathrm{GC}=$ audit opinion with the going concern explanatory paragraph. It is dummy variable, score 1 if the company get an audit opinion with a going concern explanatory paragraph, 0 if the others

ZSCORE $=$ Bankruptcy prediction model using Altman Z-Score.

$\mathrm{AUDCOM}=\mathrm{An}$ audit committee that measured by the index of audit committee performance effectiveness

$\alpha=$ constant

$\beta 2, \beta 3, \beta 4=$ regression coefficient

$\varepsilon=$ residual error

By making derivative equations from the above equation will explain whether the audit committee $(\mathrm{Z})$ can be considered a moderating variable. Here is the equation. $d Y / d X 1=\beta 2+\beta 3 Z$. The derivative equation means that $d Y /$ $\mathrm{dX} 1$ is a function of $\mathrm{Z}$, or $\mathrm{Z}$ moderates the relationship between $\mathrm{X}$ and $\mathrm{Y}$. If the significance value of the $\mathrm{X} . \mathrm{Z}$ variable is less than 0.05 , the alternative hypothesis $(\mathrm{Ha})$ is accepted. In other words, the $\mathrm{Z}$ variable can moderate the relationship between $\mathrm{X}$ to $\mathrm{Y}$, or $\mathrm{Z}$ strengthens the effect of $\mathrm{X}$ on $\mathrm{Y}$.

\section{Results}

\subsection{Descriptive Statistics Analysis}

Table 4 shows descriptive statistics analysis about the influence of financial distress (ZSCORE) as an independent variable towards acceptance of audit opinion with going concern explanatory paragraph (GC) as the dependent variable with audit committee (AUDCOM) as a moderation variable. Descriptive analysis aims to find out the distribution of data and the level of goodness each variable. The analysis was using SPSS version 23 program and obtained the result of data processing as follows:

Table 4. Descriptive statistics

\begin{tabular}{llllll}
\hline & $\mathrm{N}$ & Minimum & Maximum & Mean & Std. Deviation \\
\hline GCO & 168 & 0 & 1 & .15 & .363 \\
\hline ZSCORE & 168 & -5.08 & 24.80 & 3.9226 & 4.65330 \\
\hline AUDCOM & 168 & 3 & 14 & 10.80 & 2.611 \\
\hline
\end{tabular}


Based on Table 4 above, a total sample used in this study is 168 samples with the minimum and maximum score as the highest and lowest score of each variable. In the table, it can also see the mean score and standard deviation of each variable. The audit opinion variable with the going concern explanatory paragraph was not analyzed. It is because the descriptive analysis test was measured using a nominal measurement scale as a dummy variable ( 1 or 0$)$. This number only functions as a label of the category so that it cannot be analyzed minimum, maximum, mean, and standard deviation.

Financial distress variables are using Altman Z-Score calculation as a proxy. The table shows that the minimum Altman Z-Score calculation is -5.08, and a maximum score is 24.80. The mean score of Z-Score calculation is 3.9226, with a standard deviation score is 4.65330 . It shows that the average of sample companies in this study face a financial problem or financial distress.

The measurement of audit committee variable is using the index of audit committee performance effectiveness following the regulation made by BAPEPAM, or now it called OJK. The minimum score of the audit committee's performance effectiveness obtained number 3 , while the maximum value of the measurement index score effectiveness of the audit committee's performance is 14 . The average index score in the descriptive statistics table is 10.80 , and the standard deviation is 2,611. It means that most of the audit committee in the company sample in this study show good performance effectiveness following regulations provided by Bapepam or OJK.

\subsection{Logistic Regression Analysis}

The logistic regression hypothesis testing in this study used the Wald test. The Wald test itself is a test to determine whether the independent variables partially have a significant effect on the dependent variable. The result of the Wald test is obtaining as follows:

Table 5. Wald test result

\begin{tabular}{llllllll}
\hline & & B & S.E. & Wald & Df & Sig. & Exp(B) \\
\hline Step 1 $^{\mathrm{a}}$ & ZSCORE & -1.476 & .311 & 22.507 & 1 & .000 & .229 \\
\cline { 2 - 8 } & Constant & .319 & .386 & .684 & 1 & .408 & 1.376 \\
\hline
\end{tabular}

Table 5 shows the results of testing the ZSCORE variable on the GC variable. It obtained the Wald Statistic value of 22.507 higher than the value of Chi-Square in the table with df 1 and the significance level of 5\%, which is 3.841 . The significance value of the ZSCORE variable on GC obtained 0.000 smaller than $\alpha(0.05)$. The ZSCORE variable regression coefficient is -1.476 , which indicates that the Z-Score value has a significant negative relationship with the audit opinion with the going-concern explanatory paragraph. By hypothesis testing criteria, the hypothesis accepted. The conclusion is that the financial distress score has a negative relationship on the possibility of receiving an audit opinion with the going concern explanatory paragraph accepted.

The effect of the ZSCORE variable on GC seen through the Exp (B) value of 0.229. It means the companies that experiencing financial distress tend to receive audit opinions with a going concern explanatory paragraph. The possibilities company to receive audit opinions with a going concern explanatory paragraph of 0.229 times compared to the companies that do not experience financial distress. The lower Z-Score value of the company, the higher the possibility of receiving an audit opinion with the going concern explanatory paragraph.

\subsection{Moderated Regression Analysis}

Testing the next hypothesis uses moderating variables, so the analysis used is MRA or moderated regression analysis. The MRA in this study was used to test whether the audit committee moderated the effect of financial distress on the audit opinion with the going concern explanatory paragraph. The results of the moderated regression analysis of the effect of financial distress on the audit opinion with the going concern explanatory paragraphs moderated by the audit committee were as follows: 
Table 6. The result of moderated regression analysis

\begin{tabular}{llllllll}
\hline & B & S.E. & Wald & Df & Sig. & Exp(B) \\
\hline Step $1^{\mathrm{a}}$ & ZSCORE & .467 & .955 & .239 & 1 & .625 & 1.595 \\
\cline { 2 - 8 } & AUDCOM & .390 & .154 & 6.387 & 1 & .011 & 1.477 \\
\cline { 2 - 8 } & ZSCORE.AUDCOM & -.224 & .110 & 4.126 & 1 & .042 & .799 \\
\hline & Constant & -3.221 & 1.410 & 5.217 & 1 & .022 & .040 \\
\hline
\end{tabular}

Table 6 shows the significant score of ZSCORE.AUDCOM, namely 0,042. AUDCOM variable can be moderating the relationship of ZSCORE towards GC if the significance score of ZSCORE.AUDCOM variable lower than 0,05 . It shows that AUDCOM variable can be moderating the effect of ZSCORE towards GC $(0,042<0,05)$. However, the regression coefficient shows a negative sign $(-0,224)$. It means that AUDCOM variable weakens the relationship between ZSCORE and GC. The hypothesis of the audit committee can strengthen companies that experiencing financial distress to accept audit opinions with the going concern explanatory paragraph rejected.

\section{Discussion}

The result of logistic regression shows the effect of financial distress (ZSCORE) towards audit opinion with the going concern explanatory paragraph (GC) has coefficient regression value -1.476. It shows that the Z-Score score has a negative relationship to the audit opinion with the going concern explanatory paragraph. Besides, the Wald Statistic value obtain 22.507 is higher than the Chi-Square value of 3.841 tables. The significance value of the ZSCORE variable on GC is 0.000 smaller than $\alpha(0.05)$. The conclusion is that financial distress has a significant negative relationship on the possibility of receiving audit opinion with paragraphs going concern explanation. The lower the Z-Score value in the company, the higher the possibility of receiving an audit opinion with the going concern explanatory paragraph. Companies that have a low Z-Score means that the company is experiencing financial problems or financial distress.

The results of this study support previous research that states the more companies experience financial distress, the higher the likelihood of receiving an audit opinion with going concern explanatory paragraph (Carcello \& Neal, 2000; Knechel \& Vanstraelen, 2007; Ramadhany, 2004). The auditor will issue an audit opinion with going concern explanatory paragraph if there is a level of doubt over the ability of the company to maintain its business continuity above 50\% (Purba, 2016). 40\% of companies that bankrupt proven received the going-concern qualification in the prior year using the bankrupt prediction Z-Score approach (Altman, 2018). It means that the auditor will issue an audit opinion with going concern explanatory paragraph on the company experiencing financial distress and doubtful business continuity in the future.

The results of this study prove that the global economic crisis that has hit the last few years has led to a weakening in commodity prices. This phenomenon has caused mining companies to experience financial problems or financial difficulties and causing suspend sanctions, even delisting on stock trading by Indonesia Stock Exchange (IDX) recently. This study result supports the suspend sanction on the company that doubtful of the ability to maintain its business. This sanction aims to protect investors from mistakenly investing their funds. For this reason, investors who will buy stocks must also understand the financial condition of each company to buy and sell shares safely. One of the ways is by understanding the communication of the auditor through audit opinion with the explanatory paragraph of going concern.

The next hypothesis testing is to test the audit committee variable in moderating the effect of financial distress on the audit opinion with the going-concern explanatory paragraph so that the tests using moderated regression analysis or MRA. The moderated regression analysis results of the effect of financial distress on the audit opinion with the going concern explanatory paragraph moderated by the audit committee obtained a significance value of ZSCORE.AUDCOM of $0.042<0.05$ with a negative regression coefficient value of $-0,224$. So, the conclusion is that the audit committee is not able to strengthen the relationship of companies that experiencing financial distress to accept audit opinions with the going concern explanatory paragraph.

This research is in line with previous research; the audit committee did not affect the acceptance of going concern opinion. The existence of an audit committee does not affect the company experiencing financial distress to accept the audit opinion with the going concern explanatory paragraph (Ramadhany, 2004). It is because of the existence of the 
audit committee does not reduce the occurrence of errors and qualifications that are not compliant. The existence of the audit committee is not as effective as the Olivencia Code, good corporate governance regulations in Spain (Pucheta-martínez \& Fuentes, 2007). Audit committee members who have a professional accounting background and experience in managerial positions also do not affect the quality of the audit produced. Also, the number of independent members of the audit committee has a negative impact on bank financial performance. The more member of the independent audit committee, the lower the percentage of ROA, ROE, and NIM (Gunes \& Atilgan, 2016; Yasin $\&$ Nelson, 2012). Even the audit committees that often doing a meeting do not prevent earning management practices (Zgarni et al., 2018). It may indicate that though the audit committee has carried out the duties and responsibilities following the regulation by government and companies, it does not affect the quality of financial reporting (Wiralestari \& Tanzil, 2015).

It shows that the audit committee is not sufficient yet in maintaining the independence and objectivity of the auditor in issuing audit opinions. Even they have fulfilled the responsibility following the regulation issued by BAPEPAM or OJK. Based on the statistical test result show that as a variable moderating, the audit committee has a negative relationship. It means that the audit committee does not support the auditor in issuing audit opinions with the going concern explanatory paragraph on companies experiencing financial distress. An effective audit committee expected can suppress doubts on the auditor to issue an audit opinion with the going concern explanatory paragraph on the company that experiencing financial distress. The responsibility of the audit committee is to maintain the auditor to remain independent of management (Arens, Elder, \& Beasley, 2015). So, the financial statements provide information that more transparent, especially for the users. The results of this research test are not in line with the previous study that states the composition of members and characteristics of audit committees influence the acceptance of going concern opinion (Carcello \& Neal, 2000, 2003).

\section{Conclusion, Limitations, and Suggestions}

Based on the results of the research, we found that financial distress has a significant adverse effect on the audit opinion with the going concern explanatory paragraph. The smaller the Altman Z-Score of the company, the higher a tendency of that company to receive audit opinion with going concern explanatory paragraph. Companies that experience financial distress tend to accept an audit opinion with a going concern explanatory paragraph compared to a company that does not experience financial distress. This study result supports the suspend sanction on the company that doubtful of the ability to maintain its business. The suspend sanction aims to protect investors from mistakenly investing their funds.

For this reason, investors must understand the financial condition of each company to buy and sell shares safely. One of the ways is by understanding the communication of the auditor through audit opinion. Audit opinion with the explanatory paragraph of going concern can be the sign from the auditor that the company facing a financial problem and need corrective action to fix it.

Furthermore, we found that the audit committee's role is not able to strengthen a financial distress company to obtain an audit opinion with a going concern explanatory paragraph. It may indicate, the audit committee is not effective yet in maintaining the independence and objectivity of the auditor in issuing audit opinions. Although the audit committee has fulfilled the responsibility following the regulation, it is not sufficient yet to maintain the independence of the auditor. Mainly to issue audit opinion with going concern explanatory paragraph. It needs attention to the regulator to supervise the audit committee role - particularly the role that enhances the independence of the auditor to issuing audit opinion.

This study has a limitation. That is only focusing on phenomena that occur in the mining industry so that it does not describe the whole going concern problems of companies listed on the Indonesia Stock Exchange (IDX). Further research expected to expand the sample use of the sector broadly to see different research results. Furthermore, the proxy of the effectiveness of the audit committee's performance measurement is only through data obtained from the annual report. Further research can use the more comprehensive proxy for measuring the effectiveness of audit committees such as questionnaires or interviews with audit committee members to obtain accurate data.

\section{References}

Altman, E. I. (1968). Financial Ratios, Discriminant Analysis and the Prediction of Corporate Bankruptcy. The Journal of Finance, 23(4), 589-609. Retrieved from http://www.jstor.org/stable/2326758

Altman, E. I. (2018). Applications of Distress Prediction Models: What Have We Learned After 50 Years from the Z-Score Models?. International Journal of Financial Studies, 6(3), 70. https://doi.org/10.3390/ijfs6030070

Arens, A. A., Elder, R. J., \& Beasley, M. S. (2015). Auditing and Assurance Service an Integrated Approach (5th 
ed.). Pearson.

Blay, A. D., Geiger, M. A., \& North, D. S. (2011). The Auditor's Going-Concern Opinion as a Communication of Risk. Auditing: A Journal of Practice \& Theory, 30(2), 77-102. https://doi.org/10.2308/ajpt-50002

Carcello, J. V., \& Neal, T. L. (2000). Audit committee composition and auditor reporting. The Accounting Review, 75(4), 453-467.

Carcello, J. V., \& Neal, T. L. (2003). Audit committee characteristics and auditor dismissals following "new" going-concern reports. The Accounting Review, 78(1), 95-117.

García Blandón, J., \& Argilés Bosch, J. M. (2013). Audit firm tenure and qualified opinions: New evidence from Spain. Revista de Contabilidad-Spanish Accounting Review, 16(2), 118-125. https://doi.org/10.1016/j.rcsar.2013.02.001

Gavious, I. (2007). Alternative perspectives to deal with auditors' agency problem Alternative perspectives to deal with auditors' agency problem. Critical Perspective on Accounting, 18, 451-467. https://doi.org/10.1016/j.cpa.2006.01.011

Geng, R., Bose, I., \& Chen, X. (2015). Prediction of financial distress: An empirical study of listed Chinese companies using data mining. European Journal of Operational Research, 241. https://doi.org/10.1016/j.ejor.2014.08.016

Ghafran, C., \& O'Sullivan, N. (2017). The impact of audit committee expertise on audit quality: Evidence from UK audit fees. British Accounting Review, 49(6), 578-593. https://doi.org/10.1016/j.bar.2017.09.008

Ghodrati, H., \& Moghaddam, A. M. (2012). A Study of the Accuracy of Bankruptcy Prediction Models: Altman, Shirata, Ohlson, Zmijewsky, CA Score, Fulmer, Springate, Farajzadeh Genetic, and McKee Genetic Models for the Companies of the Stock Exchange of Tehran. American Journal of Scientific Research, 59(59), 55-67. Retrieved from http://www.eurojournals.com/ajsr.htm

Gunes, N., \& Atilgan, M. S. (2016). Comparison of the Effectiveness of Audit Committees in the UK and Turkish Banks. International Journal of Financial Research, 7(2). https://doi.org/10.5430/ijfr.v7n2p18

Ika, S. R., \& Ghazali, N. A. M. (2012, April). Audit committee effectiveness and timeliness of reporting : Indonesian evidence. Managerial Auditing Journal, 27, 403-424. https://doi.org/10.1108/02686901211217996

Inaam, Z., \& Khamoussi, H. (2016). Audit committee effectiveness, audit quality and earnings management: a meta-analysis. International Journal of Law and Management, 58(2), 179-196. https://doi.org/10.1108/IJLMA-01-2015-0006

Januarti, I. (2009). Analisis Pengaruh Faktor Perusahaan , Kualitas Auditor , Kepemilikan Perusahaan Terhadap Penerimaan Opini Audit Going Concern ( Perusahaan Manufaktur Yang Terdaftar di Bursa Efek Indonesia). Sistem Informasi, Auditing, Etika Profesi.

Knechel, W. R., \& Vanstraelen, A. (2007, May). The Relationship between Auditor Tenure and Audit Quality Implied by Going Concern Opinions. Auditing: A Journal of Practice \& Theory, 26(1), 113-131.

Kordestani, G., Biglari, V., \& Bakhtiari, M. (2011). Ability of Combinations of Cash Flow Components to Predict Financial Distress. Verslas: Teorija Ir Praktika, 12(3), 277-285. https://doi.org/10.3846/btp.2011.28

Omelka, J., Beranova, M., \& Tabas, J. (2013). Comparison of the Models of Financial Distress Prediction. Acta Universitatis Agriculturae et Silviculturae Mendelianae Brunensis, 61(7), $2587-2592$. https://doi.org/10.11118/actaun201361072587

Outecheva, N. (2007). Corporate Financial Distress: An Empirical Analysis of Distress Risk. Retrieved from http://www1.unisg.ch/www/edis.nsf/syslkpbyidentifier/3430/\$file/dis3430.pdf

Pucheta-martínez, M. C., \& Fuentes, C. De. (2007, November). The Impact of Audit Committee Characteristics on the Enhancement of the Quality of Financial Reporting: An Empirical ... The Impact of Audit Committee Characteristics on the Enhancement of the Quality of Financial Reporting: an empirical study in the Sp. Corporate Governance: An International Review, 1394-1412. https://doi.org/10.1111/j.1467-8683.2007.00653.x

Purba, M. P. (2016). Asumsi Going Concern: Suatu Tinjauan terhadap Dampak Krisis Keuangan atas Opini Audit dan Laporan Keuangan, Edisi 2. Yogyakarta: Ekuilibria.

Rahayuningsih, A. (2014). Pengaruh Kondisi Keuangan, Reputasi Auditor, Disclosure dan Opini Audit Tahun 
Sebelumnya pada Pengungkapan Opini Audit Going Concern.

Ramadhany, A. (2004). JMAKSI_Agt_2004_10_Alexander_Ramadhany.pdf. Jurnal Maksi, 4, 146-160.

Read, W. J., \& Yezegel, A. (2018, October). Going-concern opinion decisions on bankrupt clients: Evidence of long-lasting auditor conservatism?. Advances in Accounting, 40, 20-26. https://doi.org/10.1016/j.adiac.2017.12.004

Swanson, Z., \& Theis, J. (2019). Study of Going-Concern Opinions. Journal of Accounting, Auditing \& Finance, 34(3), 347-360. https://doi.org/10.1177/0148558x17706027

Triani, N. N. A., Satyawan, M. D., \& Yanthi, M. D. (2017). Determining The Effectiveness of Going Concern Audit Opinion by ISA 570. Asian Journal of Accounting Research, 2(2), 29-35.

Widhiastuti, R., Nurkhin, A., \& Susilowati, N. (2019). The Role of Financial Performance in Mediating The Effect of Good Corporate Governance on Financial Distress. Jurnal Economia, 15(1), 34-47. https://doi.org/10.21831/economia.v15i1.22927

Wiralestari, \& Tanzil, N. D. (2015). The Effectiveness of Audit Committee toward Financial Reporting 's Quality (Non-Financial Issuers Listed in Indonesia Stock Exchange). Research Journal of Finance and Accounting, 6(10), 186-190. https://doi.org/2222-2847

Yasin, F. M., \& Nelson, S. P. (2012). The Audit Committee and Internal Auditing. International Journal of Economics, Management and Accounting, 2(2), 187-218. https://doi.org/10.1002/9781119201472.ch9

Zgarni, A., Fadhila, H., \& El Gaied, M. (2018). Audit Committee and Discretionary Loan Loss Provisions in Tunisian Commercial Banks. International Journal of Business and Management, $13(3), 169$. https://doi.org/10.5539/ijbm.v13n3p169 